TPeriodica Polytechnica Civil Engineering

61(1), pp. 128-134, 2017

DOI: $10.3311 /$ PPci.8660

Creative Commons Attribution (i)

RESEARCH ARTICLE

\section{Bond of Reinforcement with Normal-weight Fiber Reinforced Concrete}

\author{
Ahsan Ali $^{1 *}$, Shahid Iqbal ${ }^{1}$, Klaus Holschemacher ${ }^{1}$, Thomas A. Bier ${ }^{2}$
}

Received 09-10-2015; accepted 14-03-2016

\begin{abstract}
In reinforced concrete members, upon loading, tensile stresses from reinforcement to concrete transfer via bond. Proper bond between the two material guarantees safety of such members. This paper presents test results performed on Pull-out specimens for evaluation and comparison of bond strength behavior of Normal-weight Fiber Reinforced Concrete (NWFC). Test parameters included reinforcement size and fiber content. Three different reinforcement sizes $(10,16$ and $20 \mathrm{~mm})$ and four concrete mixes having fiber contents of 0, 20, 40 and 60 $\mathrm{kg} / \mathrm{m}^{3}$ were used for current experimental work. In total, 36 Pull-out specimens were tested; although the size of specimens varied with reinforcement size, concrete cover to bar diameter ratio $\left(c / d_{b}\right)$ remained constant. From the selected range of fiber content used in current experimental work, dosage of $40 \mathrm{~kg} / \mathrm{m}^{3}$ was found to have positive effect on most of the concrete properties. Test results indicate decrease in ultimate bond strength with increasing bar size. The effect of fibers was not observed in enhancing the pre-crack performance of the test specimens, whereas the ultimate bond strength and post peak bond strength performance increased significantly. The ultimate bond strength is found to be strongly affected by the compressive strength rather than fiber volume.
\end{abstract}

\section{Keywords}

Concrete, Pull-out, Bond, Fibers, Hooked-end

\section{Introduction}

Concrete is the most extensively used material of construction to date and is expected to remain the priority construction material for designers and engineers for future to come. Innovations in material technology have led to the development of various types of it, subsequently drawing attention of researchers for evaluation of their properties. Among these is the Normal-weight Fiber Reinforced Concrete (NWFC), which is developed after addition of fibers of various shapes and material. Effectiveness of fibers in crack control and for improving mechanical properties like flexural performance, bond, toughness and as an alternate to minimum shear reinforcement for concrete in highly congested reinforcing areas is already well acknowledged and reported [1-4]. Also in recent years tests on using steel fiber reinforced concrete as strengthening material have shown promising results $[5,6]$.

Despite its various advantages FRC has not found its place in design codes, for example in ACI -318 [7]. Although different design approaches exist that take into consideration the additional tensile strength supplemented by fibres, uncertainty of presence of fibres in critical regions remains still a major hurdle in recognizing the enhancements made by fibres to conventional concrete. Probably for this reason design approach adopted in conventional concrete is still being followed for steel fibre reinforced concrete too.

For the past 40 years, after the development of fiber reinforced concrete, extensive research material has been published on fiber reinforced concrete and perhaps the interaction between reinforcement and concrete (Bond) is one of most investigated property. Two primary reasons for such an extensive research on bond are (1) development of new materials like fibers, admixtures, artificial aggregates etc, and (2) variety of factors influencing this interaction, like, confinement, reinforcement characteristics, test environment, etc. Comprehensive literature is available on effect of these parameters on bond strength in reports of fib [8] and ACI [9]. However there is limited data available on the effect of reinforcing bar size, specially having larger diameter on bond strength of normalweight concrete reinforced with fibers. Data from this work 


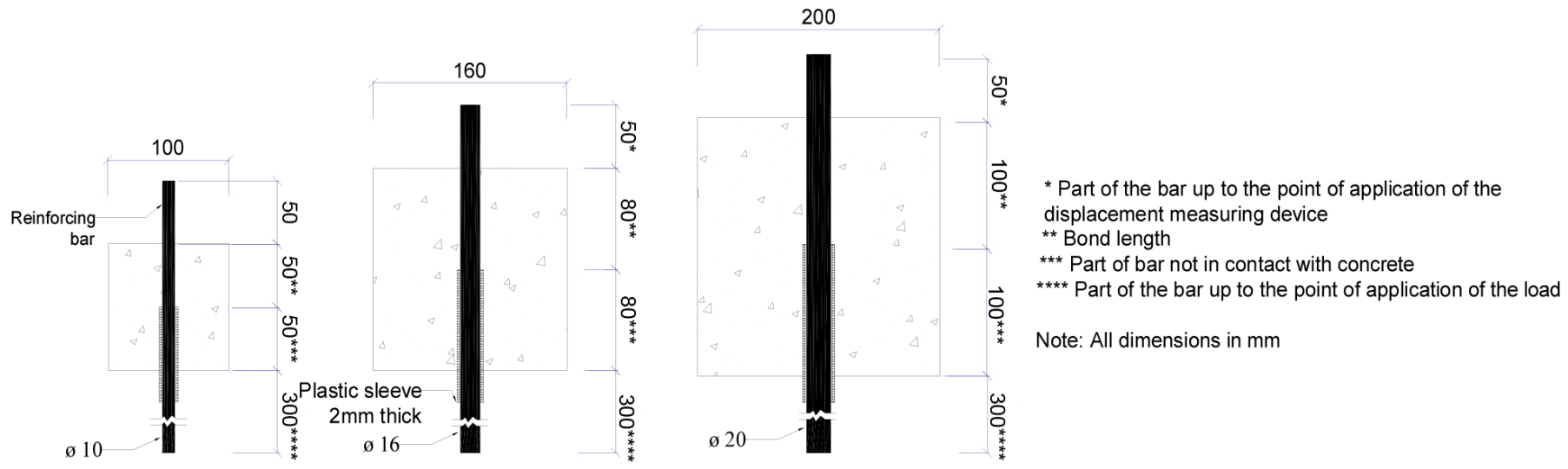

Fig. 1 Specimen details

will be available to the recognition, if any, of steel fibres on bond strength of SFRC as the design expressions used in most of the standards are based on experimental work performed on conventional concrete.

The reinforcement in a cracked segment of structural member resists large tensile stresses compared to surrounding concrete, generating strain incompatibility between the two materials. Such process ultimately leads to the axial displacement or slip of steel bar relative to the concrete. Bond stresses are induced when this slip is resisted by friction and mechanical bearing of bar. The average bond stresses from pull-out tests in laboratory are calculated by dividing pull-out force with the surface area of reinforcement that is in contact with concrete (Eq. (1)).

$$
\mu=\frac{P}{\pi l_{d} d_{b}}
$$

\section{Experimental Program}

Experimental program included testing of 36 Pull-out specimens. Specimens geometry varied in proportion to the bar being pulled (Fig. 1). This was done intentionally to have same confinement condition (cover to bar diameter ratio) for all specimens to monitor the effect of fibers only on bond behavior. Most of the guidelines for specimen design were followed from RILEM standard [10], except size. There were three (03) specimens for each bar size in every concrete mix i.e. nine (09) specimens for every mix and total 36 specimens for all the four concrete mixes. Specimens were labeled as NWFC-N1-N2-N3, where NI, N2, N3 refer to fiber content in $\mathrm{kg} / \mathrm{m}^{3}$, bar diameter, and specimen number respectively.

Ordinary Portland cement as a binder, gravel having the size range of 2-8 $\mathrm{mm}$ as coarse aggregate and sand of size 0-2 $\mathrm{mm}$ as fine aggregate were the basic ingredients for the normal weight concrete. Apart from reference mix with no fibers, three additional mixes incorporating hooked-end steel fibers in quantities of $20\left(0.25 \% \mathrm{~V}_{\mathrm{f}}\right), 40\left(0.5 \% \mathrm{~V}_{\mathrm{f}}\right)$ and $60\left(0.75 \% \mathrm{~V}_{\mathrm{f}}\right) \mathrm{kg} / \mathrm{m}^{3}$ were prepared.
These steel fibers had aspect ratio of $0.64\left(\mathrm{~L}_{\mathrm{f}}=0.35 \mathrm{~mm}\right.$, $\mathrm{d}_{\mathrm{f}}=0.55 \mathrm{~mm}$ ) and tensile strength of $1100 \mathrm{MPa}$ (Fig. 2). To control workability, Polycarboxylate Ether-based high range water reducing admixture (MasterGlenium ACE - 391) was used. Table 1 highlights the mix proportions used for making specimens.

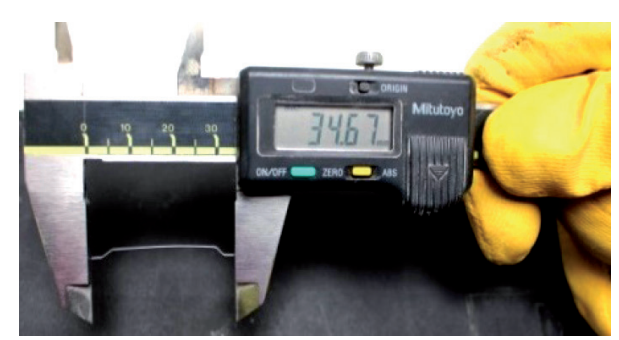

Fig. 2 Hooked-end steel fibers used in experimental work

Table 1 Ingredient proportions used in mix design

\begin{tabular}{ll}
\hline Content & Quantity \\
\hline Cement $\left(\mathrm{kg} / \mathrm{m}^{3}\right)$ & 350 \\
Fine aggregate $\left(\mathrm{kg} / \mathrm{m}^{3}\right)$ & 955 \\
Coarse aggregate $\left(\mathrm{kg} / \mathrm{m}^{3}\right)$ & 884 \\
w/c ratio & 0.45 \\
Superplasticizer $(\% *)$ & 0.5 \\
\hline
\end{tabular}

* Percent weight of cement

As mentioned earlier, modified pull-out specimens are used for current experimental work. Various test arrangements are in practice for evaluation of bond strength, and the most common include beam-end specimens, splice specimens, beam anchorage specimens and pull-out specimens. Other test specimens that have been used can also be found in the literature $[9,11,12]$. Although the stress condition around reinforcing bar in pull-out test specimen is not representative of actual scenario [8], it is however preferred for comparative studies of behavior of bond because of ease of handling and reproduction 
of specimens. Specimens were tested in $600 \mathrm{kN}$ displacement controlled machine. The bar from the specimen was pulled out at the rate of $0.005 \mathrm{~mm} / \mathrm{s}$ and the relative slip of bar against concrete was measured with the help of six LVDTs which were placed on both loaded and free end (3 LVDTs on each side) of specimen. Figure 3 shows rest of the features of test setup.

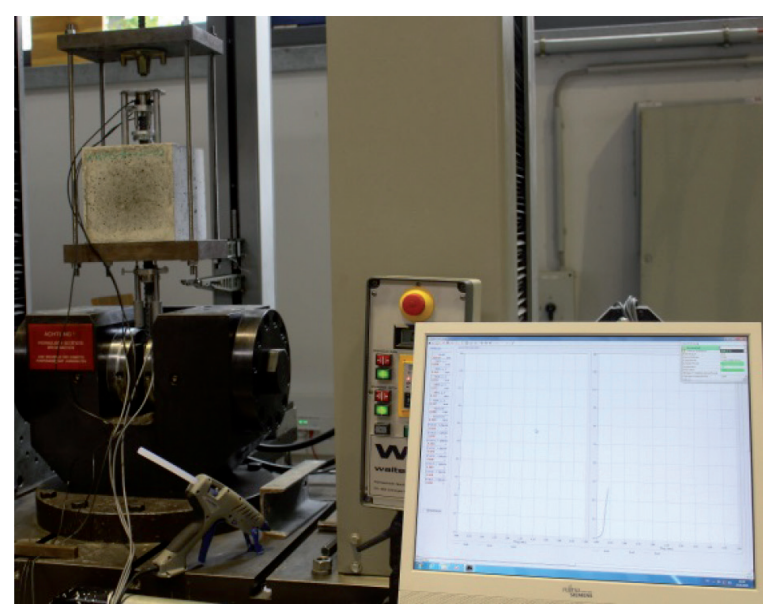

Fig. 3 Test setup

\section{Test results}

\subsection{Concrete properties}

Tests on compressive strength, splitting tensile strength, modulus of rupture and modulus of elasticity were also performed. Besides these tests, fresh concrete test results are also presented in Table 2. All these tests were performed using ASTM standards [13-15] except for workability and splitting tensile strength tests which were performed using German DIN standards $[16,17]$. Fresh concrete test results show reduction in slump flow and air-content and enhancement in concrete density as the fiber dosage increased. Results show no significant influence of fibers on compressive and splitting tensile strength. General trend of reduction in compressive strength was observed, with only exception of mix with $40 \mathrm{~kg} / \mathrm{m}^{3}$ fiber content, for which it increased about $12 \%$. Tendency of splitting tensile strength results confirm that fibers in the selected practical range cannot delay onset of crack formation. Like compressive and splitting tensile strength, first peak strength (modulus of rupture) measured by testing beams in flexure is also not greatly influenced. In this case too, beams made from mix of $40 \mathrm{~kg} / \mathrm{m}^{3}$ fiber content attained maximum increment of $19.7 \%$.

\subsection{Bond behaviour}

No pull-out failure was observed, and failure of all the specimens took place by splitting of concrete. Cracks became visible at the outer surface of all the specimens at the maximum pullout force and larger crack widths were observed with increasing bar/specimens size. Bond stress at failure was observed to decrease as the size increased because in larger specimens, due to distributed cracking, non-simultaneous nature of failure in different zones is more pronounced which help to cause the final failure resulting in larger cracks at same slip values (Fig. 4).

Effect of bar size and specimen size in different concretes on bond has been reported in earlier literature [18, 19]. These reports suggest decrease in bond strength as the bar size/specimen size increase. This decrease is attributed famous size effect law and to the fact that there is increase in circumferential shearing area as the bar diameter increases. Even with same bar size to cover ratio, results for all the mixes show that 10 mm bar size attained highest bond strength (Fig. 5 (a)). On an average bond strength of specimens with $10 \mathrm{~mm}$ bar was found to be $21 \%$ higher than those with $20 \mathrm{~mm}$ reinforcing bar.

More consistent softening branch was observed as the fiber content increased, indicating the effectiveness of fibers in trapping the progressing cracks. Also, fibers were effective in enhancing the ultimate bond strength. This increment was more pronounced in higher diameter bars at fiber dosage of $40 \mathrm{~kg} / \mathrm{m}^{3}$ with an increment of $38 \%$ for $20 \mathrm{~mm}$ bar size and $32 \%$ for $16 \mathrm{~mm}$ bar shown in Fig. 5 (b). This enhancement with increasing fiber content could be due to better bond between matrix and fibers. Disturbance in packing/density of matrix at maximum fiber content is believed to be the reason for reduction in compressive strength of concrete and thus the ultimate bond strength of $16 \mathrm{~mm}$ and $20 \mathrm{~mm}$ bars. Although, density is higher at this fiber volume (see Table 2), but, this rise is due to weight of fibers. This highlights the fact that compressive strength has strong influence on bond. Contrary to this $10 \mathrm{~mm}$ bar has improved bond strength at this fiber content $\left(60 \mathrm{~kg} / \mathrm{m}^{3}\right)$ which could be due to the presence of fibers near crack region or/and that length of fibers was adequate enough for trapping multiple cracks due to smaller size of specimens, thus delaying crack propagation and increasing bond strength, however this aspect needs further investigation. Besides improvement in ultimate bond strength, there was an increase in slip value at maximum bond stress with increasing fiber content and bar/specimen size.

Table 2 Concrete properties (Average values from 3 speciemens)

\begin{tabular}{|c|c|c|c|c|c|c|c|}
\hline $\begin{array}{l}\text { Fiber content } \\
{\left[\mathrm{kg} / \mathrm{m}^{3}\right]}\end{array}$ & $\begin{array}{l}\text { Compressive } \\
\text { strength }[\mathrm{MPa}]\end{array}$ & $\begin{array}{l}\text { Splitting tensile } \\
\text { strength [MPa] }\end{array}$ & $\begin{array}{l}\text { Modulus of } \\
\text { Elasticity [MPa] }\end{array}$ & $\begin{array}{l}\text { First peak } \\
\text { strength [MPa] }\end{array}$ & $\begin{array}{l}\text { Slump flow } \\
\text { [mm] }\end{array}$ & $\begin{array}{l}\text { Fresh concrete } \\
\text { density }\left[\mathrm{kg} / \mathrm{m}^{3}\right]\end{array}$ & Ait content $\%$ \\
\hline 00 & 37.25 & 2.75 & 31714.07 & 4.14 & 390.00 & 2243.83 & 5.30 \\
\hline 20 & 34.01 & 2.68 & 31282.02 & 4.70 & 395.00 & 2213.33 & 7.37 \\
\hline 40 & 41.98 & 2.99 & 36765.54 & 5.15 & 390.00 & 2270.60 & 5.76 \\
\hline 60 & 35.07 & 2.84 & 32553.83 & 5.04 & 365.00 & 2293.77 & 5.58 \\
\hline
\end{tabular}




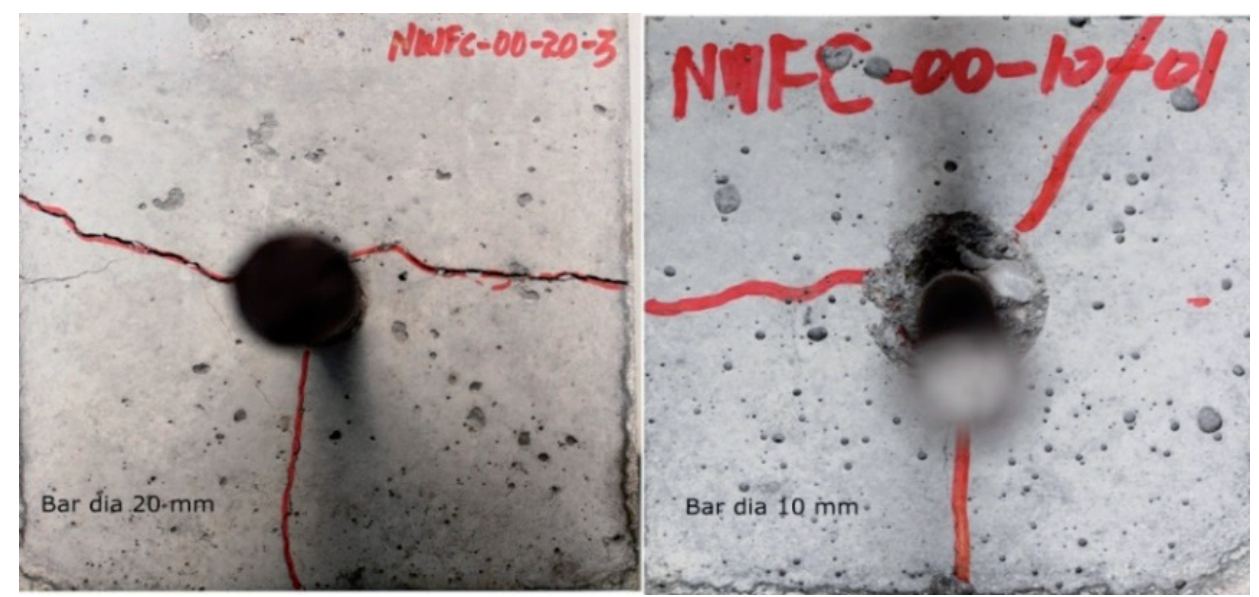

Fig. 4 Status of specimens after failure - at slip of 5
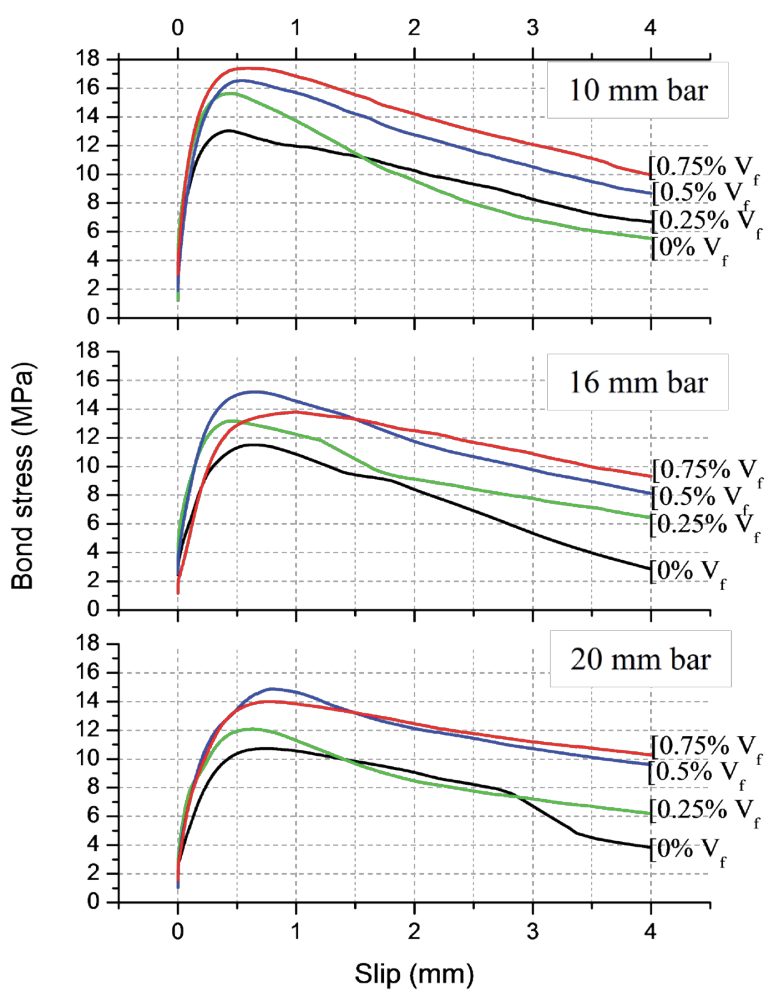

(a)
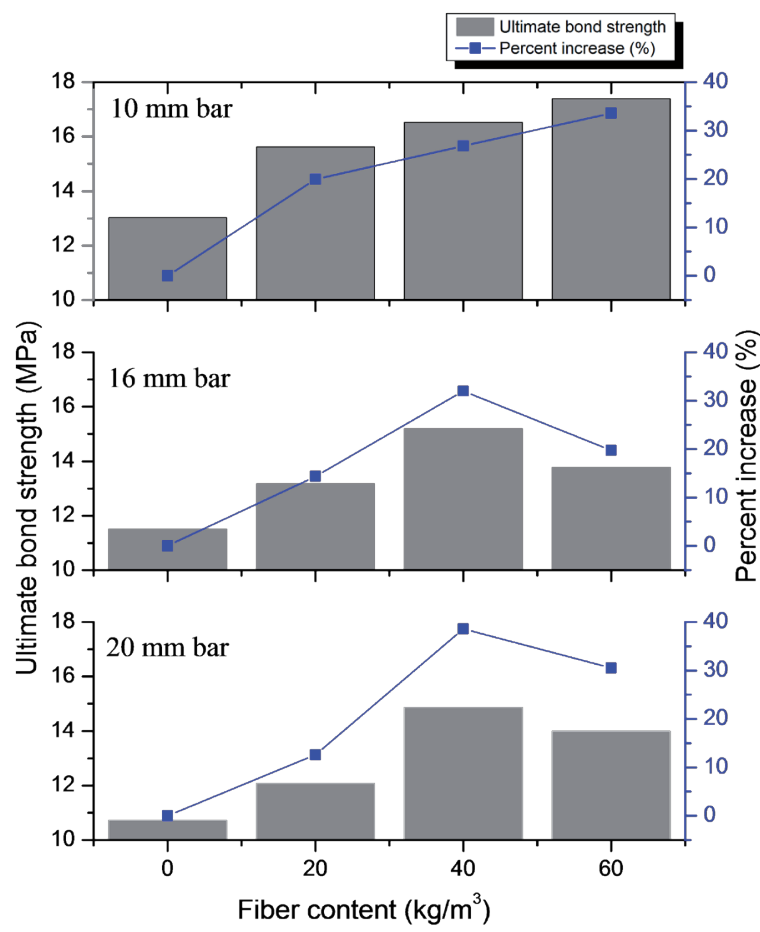

(b)

Fig. 5 (a) Bond-slip plot (b) Variation of ultimate bond strength at different fiber

\section{Estimation of Bond Strength}

Pull-out test results presented in Table 3 are compared with the equations of ACI 408 [9], fib-2010 [20] and equation given by Orangun et al. [21] on which the famous design equation of ACI-318 [7] for development length is based. This is done to find out their effectiveness in estimating bond strength of NWFC specimen because of the fact that these equations are derived from experimental results that were mostly performed on concretes containing no fibers Table 3 presents test results and prediction by these equations (Eqs. (2)-(4) respectively).

$$
\begin{gathered}
\frac{T_{c}}{f_{c}^{\prime 1 / 4}}=\frac{A_{b} f_{s}}{f_{c}^{\prime 1 / 4}}=\left[1.43 l_{d}\left(C_{\min }+0.5 d_{b}\right)+57.4 A_{b}\right]\left(0.1 \frac{C_{\max }}{C_{\min }}+0.9\right) \\
\tau_{u, s p l i t}=\eta_{2} \cdot 6.54\left(\frac{f_{c k}}{20}\right) \cdot\left(\frac{20}{\phi}\right)^{0.25} \cdot\left[\left(\frac{c_{\min }}{\phi}\right)^{0.33} \cdot\left(\frac{c_{\max }}{c_{\min }}\right)^{0.1}+8 K_{t r}\right] \\
\frac{u_{c}}{\sqrt{f_{c}^{\prime}}}=0.10+0.25 \frac{c_{\min }}{d_{b}}+4.15 \frac{d_{b}}{l_{d}}
\end{gathered}
$$




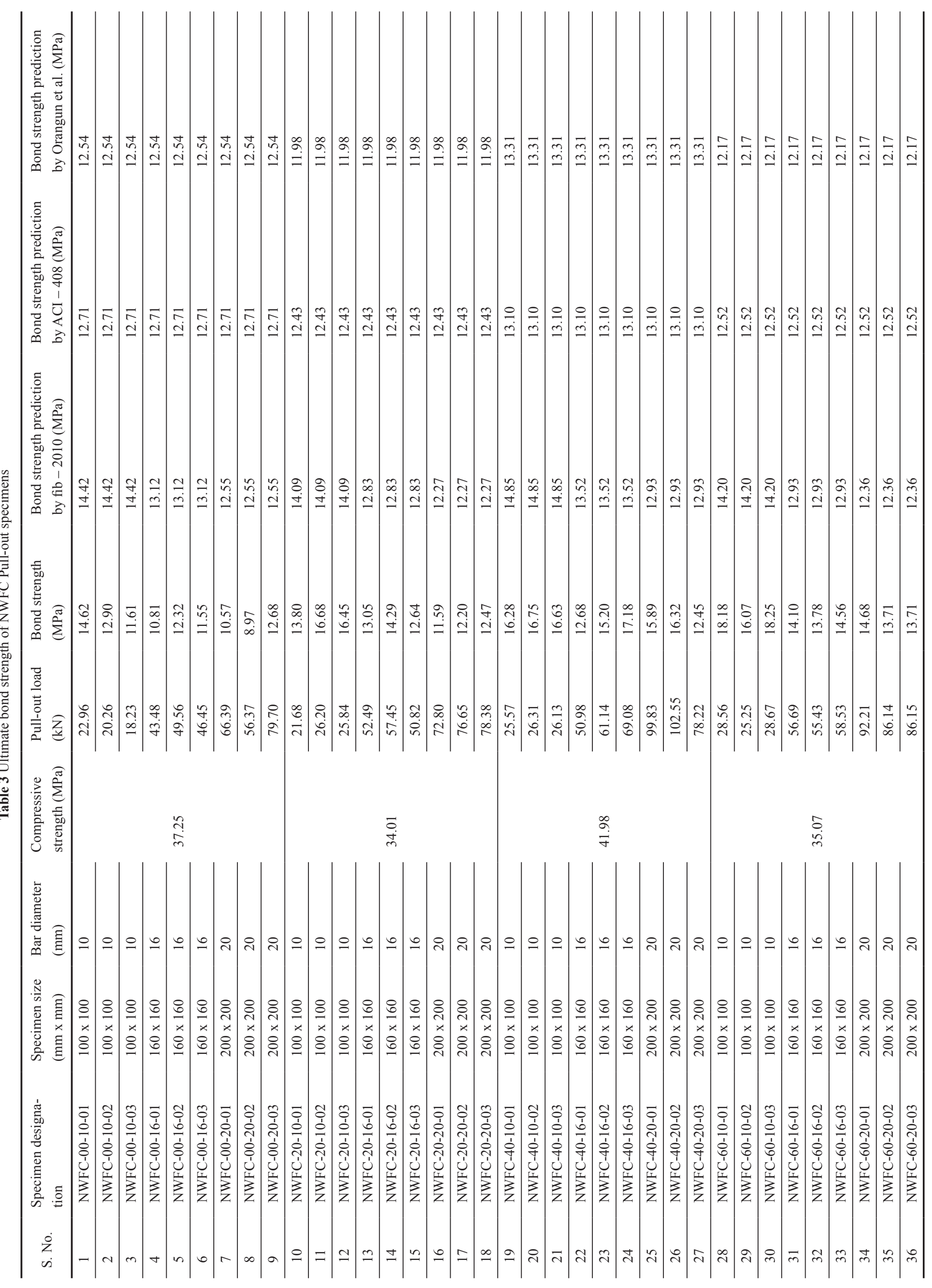




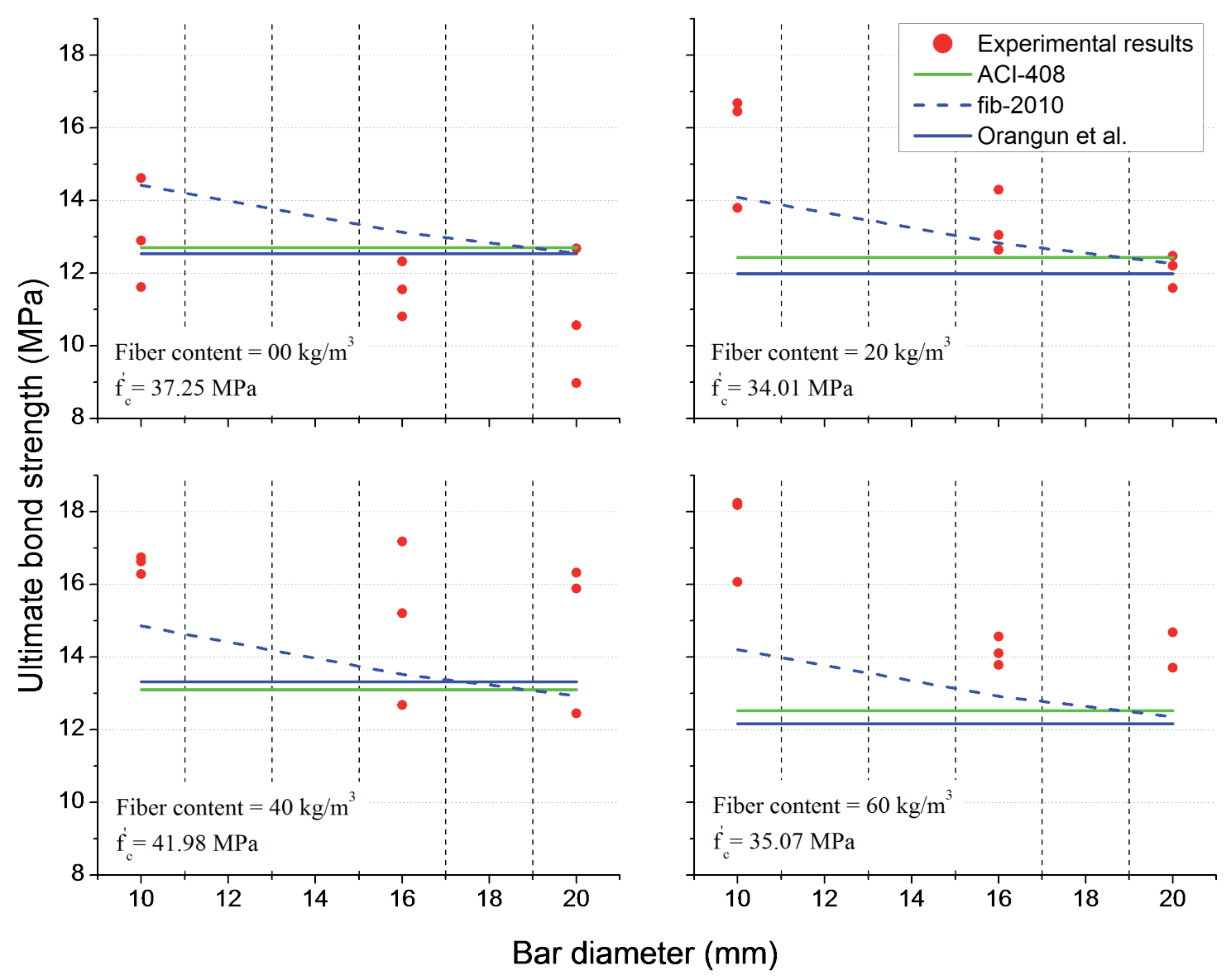

Fig. 6 Prediction of bond strength for NWFC by different equations

Here Eq. (2) is expressed in terms of bond force and must be converted to bond stress by dividing it with circumferential area $\left(\pi l_{d} d_{b}\right)$. Because of the similar cover to bar dia ratio and also similar bar dia to development length ratio, Eq. (2) and (4) yield identical bond strength results for all specimen sizes.

Equation (3), however is independent of bar size to development ratio and hence shows variation of bond strength with good prediction results (Fig. 6).

\section{Conclusions}

- Test results of 36 pull-out specimens carried out for evaluation of bond in normal weight fiber reinforced concrete are presented.

- Results show that bond strength of smallest bar used (10 $\mathrm{mm}$ bar) is found to $21 \%$ higher than largest bar size (20 mm).

- Brittle failure was more pronounced in specimens with bigger sizes. The irregular post peak profile of load-slip curve resulting from this brittleness changed to smooth consistent one as the fiber dosage increased.

- Fibers were found to influence both the ultimate bond strength and post maximum bond strength.

- It is found that for same cover to bar size ratio and bar size to development ratio, prediction of ultimate bond strength is more reasonably done by fib-2010.
- Improvement observed in softening branch of load-displacement profile of NWFC with increase in fibre content needs to be reflected in design standards, whereas for ultimate bond stress estimation Eq. (3) should be used.

\section{Notations}

\begin{tabular}{|c|c|}
\hline$A_{b}$ & Area of reinforcement \\
\hline$C_{\max }$ & Maximum concrete cover \\
\hline$C_{\min }$ & Minimum concrete cover \\
\hline$d_{b}, \phi$ & Reinforcing bar diameter \\
\hline$f_{c}^{\prime}$ & 28-days compressive strength \\
\hline$f_{s}$ & Stress in reinforcing bar \\
\hline$f_{c k}$ & $\begin{array}{l}\text { Characteristic cylinder concrete } \\
\text { compressive strength }\left(\mathrm{N} / \mathrm{mm}^{2}\right)\end{array}$ \\
\hline$k_{t r}$ & $\begin{array}{l}\text { Parameter for lateral reinforcement } \\
\text { contribution to bond }\end{array}$ \\
\hline$l_{d}$ & Bond length/Development length \\
\hline$\eta_{2}$ & Factor for bond condition \\
\hline$P$ & Applied load in flexure test \\
\hline$T_{c}$ & Bond force \\
\hline$u$ & ultimate bond strength \\
\hline
\end{tabular}




\section{References}

[1] Sahoo, D. R., Maran, K., Kumar, A. "Effect of steel and synthetic fibers on shear strength of RC beams without shear stirrups." Construction and Building Materials. 83, pp. 150-158. 2015.

DOI: 10.1016/j.conbuildmat.2015.03.010

[2] Soutsos, M. N., Le, T. T., Lampropoulos, A. P. "Flexural performance of fibre reinforced concrete made with steel and synthetic fibres." Construction and Building Materials. 36, pp. 704-710. 2012.

DOI: 10.1016/j.conbuildmat.2012.06.042

[3] Ali, A., Iqbal, S., Holschemacher, K., Bier, T. A. "Effect of Fibers on Bond Performance of Lightweight Reinforced Concrete." Periodica Polytechnica Civil Engineering. 60(1), pp. 97-102. 2016. DOI: 10.3311/PPci.8080

[4] Iqbal, S., Ali, A., Holschemacher, K., Bier, T. A. "Mechanical properties of steel fiber reinforced high strength lightweight self-compacting concrete (SHLSCC)." Construction and Building Materials. 98, pp. 325-333. 2015. DOI: 10.1016/j.conbuildmat.2015.08.112

[5] Ruano, G., Isla, F., Pedraza, R. I., Sfer, D., Luccioni, B. "Shear retrofitting of reinforced concrete beams with steel fiber reinforced concrete." Construction and Building Materials. 54, pp. 646-658. 2014.

DOI: 10.1016/j.conbuildmat.2013.12.092

[6] Martinola, G., Meda, A., Plizzari, G. A., Rinaldi, Z. "Strengthening and repair of RC beams with fiber reinforced concrete." Cement and Concrete Composites. 32(9), pp. 731-739. 2010.

DOI: 10.1016/j.cemconcomp.2010.07.001

[7] ACI 318-14: Building Code Requirements for Structural Concrete and Commentary. American Concrete Institute, Farmington Hills, MI, 2014.

[8] Fédération internationale du béton (fib): fib Bulletin 10: Bond of Reinforcement in Concrete. Lausanne, Switzerland, 2000.

[9] ACI 408R-03: Bond and Development of Straight Reinforcing Bars in Tension Reported by ACI Committee 408, vol. 03, no. (Reapproved 2012). American Concrete Institute, Farmington Hills, MI, 2003.

[10] RILEM: Technical Recommendations for the Testing and Use of Construction Materials, 2006th ed. Taylor \& Francis CRC ebook account, Kindle Edition, London, 2006.
[11] Campione, G., Cucchiara, C., La Mendola, L., Papia, M. "Steel-concrete bond in lightweight fiber reinforced concrete under monotonic and cyclic actions." Engineering Structures. 27(6), pp. 881-890. 2005.

DOI: 10.1016/j.engstruct.2005.01.010

[12] Soroushian, P., Mirza, F., Alhozaimy, A. "Bonding of Confined Steel Fiber Reinforced Concrete to Deformed Bars." ACI Materials Journal. 91(2), pp. 141-149. 1994.

[13] ASTM C39 / C39M - 14a: "Standard Test Method for Compressive Strength of Cylindrical Concrete Specimens," ASTM International, West Conshohocken, PA, 2014.

[14] "ASTM C138 / C138M - 14 Standard Test Method for Density (Unit Weight), Yield, and Air Content (Gravimetric) of Concrete," ASTM International, West Conshohocken, PA, 2014.

[15] "ASTM C1609 / C1609M - 12 Standard Test Method for Flexural Performance of Fiber-Reinforced Concrete (Using Beam With Third-Point Loading)," ASTM International, West Conshohocken, PA, 2012.

[16] DIN EN 12350-5: "Testing fresh concrete - Part 5: Flow table test, German version EN 12350-5:2009," Deutsches Institut für Normung, Berlin, 2009.

[17] DIN EN 12390-6: "Testing hardened concrete - Part 6: Tensile splitting strength of test specimens, German version EN 12390-6:2009," no. September, Deutsches Institut für Normung, Berlin, 2010.

[18] Bamonte, P. F., Gambarova, P. G. "High-Bond Bars in NSC and HPC: Study on Size Effect and on the Local Bond Stress-Slip Law." Journal of Structural Engineering. 133(2), pp. 225-234. 2007. DOI: 10.1061/ (ASCE)0733-9445(2007)133:2(225).

[19] Bazant, P. Z., Sener, S. "Size Effect in Pullout Tests." ACI Materials Journals. 85(5), pp. 347-351. 1988.

[20] Fib: fib Model Code 2010 - First complete draft, vol. 1, no. March. 2010.

[21] Orangun, C. O., Jirsa, J. O., Breen, J. E. "A Reevaluation of Test Data on Development Length and Splices." ACI Journal. 74(3), pp. 114-122, 1977, DOI: 10.14359/10993 